Матвєєв Віталій Олексійович доктор філософських наук, доцент, віцепрезидент Міжнародної Академії культури безпеки, екології та здоров'я доцент кафедри практичної психології Київського університету ім. Бориса Грінченка, бульвар І.Шамо, 18/2, м. Київ, 02154, тел.: (044) 294-00-25, e-mail: vmvitaliymatveev@gmail.com, https://orcid.org/0000-0001-9914-2233

\title{
ЗНАЧЕННЯ РОЗВИТКУ ІНДИВІДУАЛЬНИХ ЗДІБНОСТЕ В СИСТЕМІ ВИЩОЇ ШКОЛИ В АСПЕКТІ САМОРЕАЛІЗАЦІЇ ОСОБИСТОСТІ
}

Анотація. В статті аналізуються ситуація, в якій знаходиться сучасна Україна, та негативні чинники, які заважають ії успішному розвитку. Вказується на те, що пандемія короновірусу поглибила кризові явища економічного та культурно-політичного життя громадян в усьому світі, в тому числі в Україні. Зокрема це стосується проблем навчання у вищий школі. Оскільки без розвитку дистанційного навчання обійтися на даний час просто неможливо, то автор статті намагається чітко оцінити, які є позитивні і негативні моменти цього процесу. Він вказує на ту небезпеку, яка криється в переході (особливо це стусається молодих людей) в так звану «віртуальну реальність»В статті вказується, що проблема розвитку індивідуальних здібностей людини або, іншими словами, проблема самореалізації, на даний момент являється однією 3 кардинальних проблем сучасності, що потребує не тільки грунтовного дослідження, але й активного впровадження в життя.Автор наполягає на тому, що відсутність цілісної національної системи самореалізації особистості розвиток нашої країни в усіх його напрямах. Іншими словами, розвиток суспільства та індивідуальний розвиток людини відносяться один до одного як загальне до конкретного i взаємообумовлюють, взаємовизначають та взаємодоповнюють один одного. Автор також намагається проаналізувати таке неоднозначне явище, як «трансгуманізм», який отримує досить значну популярність серед інтелігенції. Порівнюється гуманізм і трансгуманізм. Вказується, що трансгуманізм може нести в собі загрозу для існування людства, оскільки питання чи збережуться в цій філософсько-психологічній течії гуманні засади є відкритим. Робиться висновок, що перед школою (а особливо - вищою) стоїть нелегка проблема відповісти на всі виклики, що стоять перед нею, бо саме вона виховує громадян майбутнього. Автор намагається довести, що назріла необхідність переходу вищої школи від екстенсивного шляху формування знань (який, в основному, полягає в їх засвоєнні на логічному рівні) до інтенсивного, який полягає в застосуванні передових технологій розвитку здібностей самої людини, тобто надання студентам цілісної системи самореалізації особистості. 
Ключові слова: глобальні проблеми, вища школа, пандемія короновірусу, дистанційне навчання, антропоцентризм, гуманізм/, штучний інтелект, тест А.Тюрінга, трансгуманізм, цифрова цивілізація, самореалізація особистості.

Matveev Vitaliy Oleksiyovish Doctor of Science in philosophy, Associate Professor, Vice President International Academy of Safety, Ecology and Health, Associate Professor them.Borys Grinchenko Kyiv University of the department Practical Psychology, Boul. I.Shamo, 18/2, Kyiv, 02154, tel.: (044) 294-00-25, e-mail: vmvitaliymatveev@gmail.com, https://orcid.org/0000-0001-9914-2233

\title{
THE VALUE OF THE DEVELOPMENT OF INDIVIDUAL ABILITIES IN THE SYSTEM OF HIGHER EDUCATION IN THE ASPECT OF SELF- REALIZATION OF PERSONALITY
}

\begin{abstract}
The article analyzes the current situation in Ukraine, and the negative factors that hinder its successful development. It is pointed out that the pandemic of coronavirus has deepened the crisis of economic and cultural-political life of citizens all over the world, including Ukraine. In particular, this applies to the problems of higher education. The development of distance learning is necessary at the present time, therefore the author of the article is trying to clearly assess the positive and negative aspects of this process. He points out the danger that lies in the transition (especially for young people) in the so-called "virtual reality". The article indicates that the problem of the development of individual abilities of a person, or, in other words, the problem of self-realization, in the present moment is one of the cardinal problems of our time, it requires not only thorough research, but also active implementation in life. The author insists that the absence of an integral national system of self-realization of personality affects the development of our country in all directions. In other words, the development of society and individual development of personalitymutually condition, mutually define and complement each other. The author also tries to analyze such an ambiguous phenomenon as "transhumanism", which is gaining quite a lot of popularity among the intelligentsia. Humanism and transhumanism are compared. It is indicated that transhumanism can pose a threat to the existence of mankind, since the question of preserving the humane foundations in this philosophical and psychological trend remains open. It is concluded that the school (and especially-the higher school) must answer all the challenges thrown to her, because it is she who educates the citizens of the future. The author is trying to prove that there is a need for the transition of higher education from an extensive path of knowledge formation (which mainly consists in their assimilation at the logical level) to an intensive one. It consists in the use of advanced technologies of the development of the abilities of the person himself, that is, providing students with an integral system of self-realization of personality.
\end{abstract}

Keywords: global problems, higher school, pandemic of coronavirus , distance education, anthropocentrism, humanism, rtificial intelligence, A. Tyuring's test, transhumanism, digital civilization, self-realization of personality. 
Постановка проблеми. Ми живемо в надзвичайно складний час. Пандемія короновірусу поглибила кризові явища економічного та культурно-політичного життя громадян в усьому світі, в тому числі в Україні. В першу чергу удар отримали малозабезпечені верстви населення, безробітні, хворі та люди похилого віку. Багато людей практично знаходяться в стані близькому до виживання, що $\epsilon$ принизливо як для них самих, так і для суспільства в цілому, яке не може забезпечити своїм громадянам право на гідне життя. Тому проблема самореалізації, на даний момент являється однією з кардинальних проблем сучасності, що потребує не тільки грунтовного дослідження, але й активного впровадження в життя.

Відсутність цілісної національної системи самореалізації особистості, на наш погляд, гальмує розвиток нашої країни в усіх його напрямах, оскільки історія діє через конкретний морально-психологічно-духовний зріз окремої особистості, соціальної групи, народу, всієї нації в цілому, і саме це визначає іï поступ. Іншими словами, розвиток суспільства та індивідуальний розвиток людини відносяться один до одного як загальне до конкретного і взаємообумовлюють, взаємовизначають та взаємодоповнюють один одного.

Аналіз останніх досліджень і публікацій. Вважаємо, що при дослідженні проблеми самореалізації особистості, доцільно використати як базові, праці таких українських вчених, як: В.П. Андрущенко, М.О. Булатов. Л.В. Губерський, А.М. Срмоленко. А.С. Конверський, А.М. Лой, С.Б. Кримський, І.Ф. Надольний, В.Г. Табачковський, Н.В. Хамітов, В.І. Шинкарук та ін. Методологічно плідними можуть бути також роботи таких українських авторів, як: А.М. Сфремов, Є.А. Іваненко, В.І. Коцюбинський, І.О. Мартинюк, М.М. Михайлов, В.І. Муляр, Т.Б. Нечипоренко, Б.Д. Паригін, О.Н. Рубан, Л.В. Сохань, В.О. Тихонович, 3.1. Файнбург, А.К. Чаплигін, І.В. Чорноморденко, О.В. Шишкін та ін., які безпосередньо за останні роки торкаються проблеми самореалізації людини.

Підкреслюючи актуальність цієї проблеми, також необхідно вказати на той факт, що, не зважаючи на досить велику кількість літератури, де висвітлюються аспекти самореалізації особистості, до сих пір не існує ні єдиної концепції самореалізації особистості, ні єдиної методологічної бази для визначення даного поняття; більш того, сам термін «самореалізація» до недавнього часу був відсутнім у вітчизняній довідковій літературі, так само як і в довідковій літературі країн ближнього зарубіжжя. Однією з спроб заповнити цю лакуну $є$ стаття автора в співавторстві 3 Н.Хамітовим «Самореалізація особистості» в словнику 3 філософської антропології, де самореалізація особистості розглядається в першу чергу як «найповніше розкриття здібностей талантів $\mathrm{i}$ потенцій особи у фізичному, моральному, інтелектуальному, душевному i духовному аспектах» [1, с.319].

Заради справедливості треба зазначити, що українська психологічна наука плідно працює в цьому напрямку, але на погляд автора, вирішивши цю проблему можна лише інтегрувавши дослідження психологів, філософів, культурологів, екологів, політологів та інших дослідників. 
Мета статті - дослідити значення і перспективи вирішення проблеми самореалізації особистості в Україні та в першу чергу у вищій школі за рахунок створення системи розвитку індивідуальних здібностей людини

Виклад основного матеріалу. Цікавість до людини як об'єкта дослідження, яку ми можемо спостерігати на даний час в усьому світі, викликана, очевидно, ще однією причиною. Вона полягає в тому, що вже більше трьох століть, починаючи 3 епохи Нового часу і навіть включаючи кінець Ренесансу, західний світ йде шляхом розвитку науково-технічного прогресу. Як відомо, в епоху Відродження спостерігалася тенденція до розвитку індивідуальних можливостей людини. В Новий же час всі надії, пов'язані з розвитком суспільства, покладали на розум та науку. Що стосується реалій сьогодення, то, приймаючи до уваги дію закону діалектики «заперечення заперечення», який вказує на те, що розвиток йде не по висхідній лінії, а по спіралі, стає зрозумілим, що ні наука, ні розвиток науковотехнічного прогресу не можуть вирішити до кінця проблеми людства і зробити його щасливим. Навпаки, цей шлях на даний час привів до глобальних проблем, які загрожують перерости в глобальну катастрофу. Можна констатувати, що нестабільність існування $є$ характерної рисою існування людства в XX - початку ХХІ століття.

Необхідно зазначити, що ще в епоху Нового часу раціоналізм, котрий розвивався під впливом капіталістичного способу виробництва, заклав основи детерміністської картини світу та теоретико-наукового розуміння природи. На противагу античним, середньовічним і навіть ренесансним уявленням про гармонійний, завершений і одухотворений космос, природу почали уявляти як безмежну, однорідну матеріальну субстанцію, а природні процеси почали розглядати в якості дії сліпих механічних сил. Такий механіцизм та утилітаризм в підході до розуміння природних і суспільних явищ призвів до суттєвої деформації ренесансного гуманізму, оскільки людину також почали сприймати як свого роду механізм, хай хоч і досконалий, або, в кращому випадку, як майстра, а оточуючий світ, природу, відповідно - як своєрідну майстерню, де майстер вільний чинити так, як йому заманеться або, точніше, виходячи зі своїх власних прагматичних потреб.

Але на даний час стає очевидним, що така форма гуманізму і, відповідно, концепція справедливості, що випливає з нього, базується на невірній або ж, в кращому випадку, застарілій картині світу: на вірі в безкінечність ресурсів, що знаходяться в розпорядженні цивілізації, а також в безкінечність тривалості індустріального прогресу, що не має просторово-часових обмежень. Така пануюча тенденція розвитку знаменується невблаганним наступом технічного світу на життєвий світ, на середовище органічних форм та породжує відчуження людини в соціумі. Таким чином, виходячи із загально-філософської, психологічної та екологічної точки зору, така форма “антропоцентричного" гуманізму грішить суб'єктивістськими й волюнтаристськими установками, оскільки ставлення до людини, до послуг якої начебто рухалась вся еволюція природи, породжує в якості невід'ємного доповнення, жорсткоутилітарне, 
прагматичне і насильницьке ставлення до оточуючого середовища, що загрожує підірвати основи життя на Землі, а разом 3 тим i кінцеву основу самого гуманізму.

Віртуалізація та інформатизація все більше входить в наше буденне життя, кардинальним чином змінюючи його в усіх культурних проявах. 3 одного боку, розвиток штучного інтелекту значно полегшує отримання нових даних, обробку інформації, процеси керування складними і надскладними системами. 3 іншого ж боку - їхнє інтенсивне впровадження створює певну загрозу приватному життю людей, яке закріплене в Конституції України (Стаття 4.2.8) Право про недоторканість особистого життя) та конституціях інших держав. Але чи діє це право у нас на Україні, чи захищена людина цим правом? Зараз вам можуть запросто подзвонити по мобільному телефону, звернувшись на ім'я та побатькові, представитися генеральним директором якоїсь фірми чи банку, і за допомогою хитрих маніпуляцій видурити у вас значну суму грошей.

Нова епоха, в якій ми живемо і яку вже можна назвати інформаційноцифровою також характеризується інтенсивним розвитком штучного інтелекту. Уже зараз роботи, або як їх скорочено називають «боти», не тільки здійснюють керування різноманітною технікою, але й пишуть музику, оповідання, успішно виграють у чемпіонів з шахів і навіть гри «го», яка побудована на інтуїції, якої, як до сих пір вважалося, позбавлений штучний інтелект, успішно проходять тест А.Тюрінга, який полягає в тому, що робот повинен переконати людину в тому, що $з$ нею спілкується не машина, а людина тощо. В ході подальшого входження в наше життя цифрових технологій, з'являється все більше інформації про те, що штучний інтелект не тільки може діяти як програмована, але й як самопрограмована система, і тому може виходити 3-під контролю людини, яка іiі створила. При чому вже є факти, які про це свідчать.

Оскільки жодні соціальні зміни не обходяться без певної філософськопсихологічної рефлексії, то можна зазначити, що на світову культурну арену виходить таке неоднозначне явище як «трансгуманізм», який отримує досить значну популярність серед інтелігенції.

3 одного боку, трансгуманізм обіцяє прекрасне майбутнє людству: довге життя без хвороб і страждань, розвиток індивідуальних здібностей за допомогою нанотехнологій, посилення і покращення своїх індивідуальних якостей тощо. Але при цьому треба також враховувати, що трансгуманізм досить суттєво відрізняється від гуманізму, який пропагувався та, власне, й пропагується до сих пір європейською філософсько-психологічною думкою, починаючи 3 доби Відродження. В той же час, якщо гуманізм на чолі світобудови ставить людину, що теж $\epsilon$ не досить вірно, оскільки людина $\epsilon$ частиною природи i такий антропоцентризм, власне, привів до екологічної проблеми, яка загрожує перерости в глобальну катастрофу, то трансгуманізм орієнтується не на людський розум, а на штучний інтелект, цифрові та нано-технології, які можуть і повинні створити $з$ людей, свого роду, андроїдів або кіборгів, які будуть відрізнятися від звичайного Гомо сапієнса посиленим інтелектом, феноменальною пам'яттю, 
можливістю безпосередньо черпати інформацію з Інтернету, а також фізичними можливостями за допомогою наприклад, застосування екзоскелетів, що вже робиться в багатьох арміях світу, інших технічних засобів, що пропонуються в якості імплантів для посилення зору, слуху тощо. Це, безперечно, буде породжувати протиріччя - якщо не повне протистояння між звичайними людьми і представниками цифрової ери - кіборгами, андроїдами, якими можуть стати люди, до яких застосовуються високотехнологічні модифікації. В той же час, кіборги не тільки здатні володіти арсеналом технічних засобів, що буде робити їх суперлюдьми, але й напряму залежати від цих просунутих технологій, збій яких може привести до непередбачуваних результатів. Тому зараз не лише в романах письменників-фантастів, або філософів-футурологів, але й серед різноманітних вчених ведеться дискусія про можливий бунт або війну машин 3 людством, що може привести до його загибелі. Таким чином, реально допустити, що трансгуманізм може нести в собі загрозу для існування людства, оскільки питання чи збережуться в цій філософсько-психологічній течії гуманні засади $€$ відкритим.

Більшість науковців все ж схиляються до думки, що штучний інтелект ніколи не замінить людину з її багатим внутрішнім світом, почуттями, емоціями, нарешті, інтуїцією. Яскравим прикладом цього $є$ історичний факт, що мав місце в далекому 1983 році, та який замовчувався в колишньому Радянському Союзі, але став широко відомим за рубежем. Так, до офіцера протиракетної оборони Станіслава Петрова надійшла інформація про запуск 5 американських ракет, які, начебто були запущені в бік Радянського Союзу. В часи правління Ю.Андропова ситуація була гранично нестабільною і таке могло трапитися буквально кожної хвилини. Перед офіцером С.Петровим постала надзвичайно складна задача - або діяти формально за інструкцією, а це означало не що інше, як початок Третьої світової війни, або, втрачаючи дорогоцінний час, ще раз перевірити дані комп'ютера, який, можливо, дав збій i, С.Петров, незважаючи на величезний ризик, обрав останнє. Ввійшовши в історію як людина, що врятувала світ від Третьої світової війни, він був нагороджений в Дрездені премією міжнародної суспільної організації «Асоціація громадян світу» [2 ].

Аналізуючи формування світогляду людини в будь-яку епоху, можна зазначити, що сім'я завжди була тим «осередком суспільства», де $з$ молоком матері закладалися перші уявлення про світ, про добро, зло, інші морально-етичні категорії. На даний час в Україні майже половина, а за деякими даними Інтернету, навіть більша частина працездатного населення працює за кордоном, заробляючи, таким чином, на прожиття своєї сім'ї, але це знову ж таки негативно позначається на вихованні дітей, оскільки вихованням займається вулиця та Інтернет. Отже, на вчителя, викладача покладається подвійна відповідальність за сім'ю і за школу.

Беручи до уваги слова видатного німецького канцлера Отто Бісмарка «Дайте мені дві тисячі вчителів і я побудую нову Німеччину», можна зазначити, що вони були і є вельми актуальними для всіх часів і всіх народів, оскільки для нових 
реалій повинен бути вихований також носій нових соціальних умов (чого, до речі, не було зроблено під час радянської «перебудови» і не зроблено, на жаль, до сих пір). Але ситуація, в якій знаходиться сучасний європейський вчитель i, в першу чергу, український, - $\epsilon$ набагато складнішою ніж за часів Бісмарка. В тогочасному суспільстві діяли певні релігійні, моральні, ідеологічні засади, замість певної розмитості і аморфності останніх на сьогоднішній день. Постать вчителя була безумовним авторитетом. Він володів обсягом знань, що набагато перевищував рівень знань своїх учнів. До нього зверталися для отримання будьякої інформації. Зараз же учні більше довіряють комп'ютеру, з яким певна частина вчителів спілкуються все ще «на ви», причому учні здебільш краще орієнтуються в Інтернет-просторі, вони проявляють більшу пристосованість до нової цифрової ери, що, безумовно, змінює технократичну. Вчителі ж нерідко демонструють певну розгубленість перед новими реаліями життя, тому їм важко власним прикладом вказати учням на чіткі морально-аксіологічні та психологічні орієнтири, щоб слугувати прикладом власної успішності.

В зв'язку з пандемією короновірусу постраждала не тільки економіка, але й освіта, яка змушена була перейти на дистанційну систему навчання.

Не можна, звичайно, говорити про те, що перехід навчання на дистанційну освіту застав всіх викладачів як середньої, так і вищої української школи зненацька. Подібна практика хоча й обмежено, але вже мала місце. В той же час, можна цілком погодитися зі словами Голови парламентського комітету з питань освіти та науки, представника партії «Слуга народу» Сергія Бабака, який в інтерв'ю Радіо Свобода від 2-го липня 2020 року заявив, що Україна не готова до дистанційного навчання в умовах, що пов'язані з викликами коронавірусу. За його словами, наразі дистанційна освіта і онлайн-освіта в Україні не можуть замінити очну освіту, а лише можуть слугувати «додатковим інструментом» для отримання знань [3].

Але, оскільки без розвитку дистанційного навчання обійтися на даний час цілком і повністю неможливо, то потрібно чітко оцінити, які $є$ плюси і мінуси цього процесу.

До позитивних моментів можна віднести:

1. Учень або студент може прослухати і побачити уроки чи лекції найкращих викладачів, якщо вони розміщені в Інтернеті.

2. Він може зробити це в будь-який зручний для нього час і зробити це стільки разів, скільки йому потрібно для кращого засвоєння навчального матеріалу.

3. Дистанційне навчання є вельми корисним для людей з особливими потребами, різного роду інтровертами, тобто тих, кому знаходження в колективі створює певні психологічні труднощі.

4. Дистанційне навчання $є$ незамінним під час пандемії, згадаймо слова гоголівського героя: «За відсутністю гербової - пишуть на поштовій».

В той же час, дистанційна освіта має свої недоліки: 
1. Людина, як відомо, істота соціальна і навряд чи щось може замінити живе спілкування не тільки в плані «викладач-учень», але й школярів та студентів між собою, що породжує в останніх певну відчуженість.

2. Дистанційна освіта може сприяти процесу залежності людини від комп'ютера i це останнє може нести негативні наслідки, що може згубно впливати на соматичне та психічне здоров'я підростаючого покоління.

3. Без достатньо розвинутої внутрішньої дисципліни школяру або студенту інколи важко спонукати себе сумлінно відпрацювати навчальні завдання, хоча в колективі він міг зробити це набагато легше.

Можна зазначити, що вже зараз значна кількість молодих людей в без дистанційного навчання більше часу проводить за комп'ютером в так званій віртуальній реальності, ніж в реальності буденній. До чого це може привести, служить яскравим прикладом російський фільм «Блатні пси» (2020 р. реж. не вказаний в ютубі), де показана доля молодого хлопця, студента, талановитого, а може навіть геніального, комп'ютерника. Друзі ласкаво називали його Додиком, для більшості оточення він був «ботаніком» - людиною «не від світу цього», зануреного в свій віртуальний простір, абсолютно не агресивним, не маючим поняття як поводитися зі зброєю. Але, попавши волею долі в злочинне середовище під владу закоренілого злочинця-вбивці Мірзи, він сам стає серійним вбивцею, уже розглядаючи кожне наступне вбивство, як свого роду, перехід на новий рівень в комп'ютерній грі. Закінчується це тим, чим, власне, й повинно було закінчитися - його самого вбивають [4.].

Таким чином, проаналізувавши ситуацію, в якій знаходиться людство i українське суспільство зокрема, можна сказати, що перед школою (а особливо вищою) стоїть нелегка проблема відповісти на всі виклики, що стоять перед нею, бо саме вона виховує громадян майбутнього.

Не так давно була розроблена і затверджена «Концепція нової української школи» (документ пройшов громадські обговорення і ухвалений рішенням колегії МОН 27/10/2016). В даному документі вказується: «Нова українська школа - це ключова реформа Міністерства освіти i науки. Головна мета створити школу, в якій буде приємно навчатись і яка даватиме учням не тільки знання, як це відбувається зараз, а й уміння застосовувати їх у повсякденному житті.» [5.].

Аналізуючи ж процес підготовки спеціалістів різного профілю в сучасній вищій школі, можна зазначити, що він характеризується певною суперечливістю і навіть парадоксальністю, на що автор вказував в інших публікаціях [6]

Введення Болонської системи, з одного боку, дозволило нашим студентам в певній мірі наблизитися до європейських стандартів навчання, а з іншого ж боку зменшення кількості аудиторних годин i відповідне збільшення годин, що відводяться на самостійну роботу, погіршило якість освіти, оскільки як відомо «західний студент вчиться - нашого вчать». Тому сподівання, що вітчизняний студент буде інтенсивно оволодівати знаннями, проявляючи при цьому чудеса свідомості і відповідальності, в більшості випадків є досить утопічними. 
Інше важливе протиріччя у викладанні гуманітарних дисциплін полягає у тому, що з одного боку, в навчальному процесі присутні конкретні дисципліни, які стосуються окремих проблем людини (психологія, педагогіка, етика, естетика, соціологія, історія та ін.). А з іншого боку, є нагальна потреба в дисциплінах, які давали б змогу репрезентувати людську особистість в аспекті іiі розвитку, самореалізації та надавали б конкретні рекомендації до застосування теорії на практиці.

Крім того, стає все більш зрозумілим, що безупинне вдосконалення техніки вимагає такого ж вдосконалення і від сучасної людини. Людська діяльність стає все складнішою і потребує все більш високого інтелектуального і фізичного потенціалу, максимальної адаптивності, здатності швидко оцінювати ситуацію, вміння ефективно оперувати постійно зростаючим обсягом інформації, швидко і відповідально приймати рішення.

В 1990 р., за часів існування Радянського Союзу, трьом вишам, а саме Московському державному педагогічному інституту ім. B.I. Леніна, Ленінградському державному педагогічному інституту ім. А.I. Герцена та Луцькому державному педагогічному інституту ім. Лесі Українки було доручено розробити навчальні курси 3 людинознавства. В Луцьку цією проблемою займався доктор філософських наук, професор Р.А. Арцішевський, автор першого підручника «Світ і людина» [7] для школярів 8-го класу. Ним була створена кафедра людинознавства, відкритий факультет перекваліфікації 3 даної дисципліні, створений Республіканський центр світоглядної освіти молоді, а потім на базі Центру - Інститут соціальних наук. Однак, маючи деякі труднощі фінансово-матеріального характеру та певну віддаленість Луцька від центру, кафедра була реформована і відійшла від своєї основної проблематики.

В березні 2005 року в Національному педагогічному університеті імені М.П. Драгоманова була заснована кафедра філософської антропології, почали розроблятися нові перспективні теми, регулярно проводитися конференції, семінари, круглі столи, виступи на радіо-телебаченні тощо. Але на даний момент, завдяки певним консервативним тенденціям, які спостерігаються на факультеті філософії і суспільствознавства, кафедра філософської антропології припинила своє існування. Що ж стосується Київського національного університету ім. Тараса Шевченка, який $\epsilon$, свого роду, флагманом української вищої освіти, то подібна кафедра так, на жаль, і не була створена. Хоча, виходячи 3 відомої на даний момент тези, що олюднення усього простору соціальних відносин, визнання неповторності, самобутності кожної людини за вищу цінність, визначає як стратегічну мету держави, яка претендує на статус демократичної, можна зробити висновок про необхідність введення не лише створення подібних кафедр, а й відкриття нової спеціальності за назвою «Проблеми розвитку людини» або «Людинознавство».

На даний час великі надії в цьому плані можна покладати на Київський університет імені Бориса Грінченка, де створений Інститут людини і проблема розвитку особистості вирішується, в першу чергу, 3 позицій психології i 
відповідних тренінгів, хоча на думку автора статті, це не тільки психологічна, але й, в першу чергу, філософська проблема.

Таким чином, головним недоліком вищої школи є те, що вона, даючи певний обсяг знань, не в повній мірі розвиває індивідуальні здібності студента, не вчить вчитися і переучуватися, а лише надає певні знання. За останніми дослідженнями соціологів, в наш час європеєць змінює в середньому чотири рази кваліфікацію за своє життя i тому вміння переучуватися $\epsilon$ органічною складовою процесу навчання.

Не викликає сумніву, що процес підготовки будь-якого спеціаліста як гуманітарного, так і не гуманітарного профілю повинен починатися з формування у студента найбільш загальних, філософських, інтегративних уявлень про людину, що базуються на таких засадних принципах, як гуманізм, системність, цілісність та ін. (причому бажано, щоб цей процес починався ще в школі). Це повинно створити базу для поглибленого вивчення більш конкретних дисциплін, що розглядають людину в конкретних сферах іiі життєдіяльності, таких як праця, родина, освіта, культура, політика, екологія та ін. Такий підхід робить можливим здійснення справжньої гуманізації освіти, про яку так багато говорять в останні роки.

Ця спеціальність також повинна бути спрямована на відродження, збереження та зміцнення традицій українського народу, на подолання комплексу власної меншовартості та існуючого ідеологічного вакууму, на згуртування, об'єднання людей, досягнення єдності поколінь, етносів, націй і народностей, що проживають в Україні та є їі повноправними суб'єктами. Вона також повинна формувати повагу до людини, людства, народу, нації і держави, культури i моралі, повагу до батьків, до сім'ї і громадян, влади і загальнонародних святинь. Ця спеціальність повинна базуватися на визнанні цінності кожної людини, свободи ii індивідуального вибору, захисту права особистості на власний спосіб самореалізації за умов іï соціальної та етичної значущості.

Студент, що пройшов курс вивчення даної спеціальності повинен грунтовно оволодіти системою знань про сутність людини, природи, суспільства, їх спосіб існування, про закономірності, тенденції та перспективи соціального поступу як людства в цілому, так і українського суспільства особливо. Світогляднофілософські дисципліни, в тому числі філософська антропологія, філософія культури, філософія науки, філософія політики, філософія права тощо, повинні утворювати базу даної спеціальності, оскільки це допомагає оволодіти фундаментальними знаннями про навколишній світ, природу, довкілля. Всесвіт, основні закономірності взаємодії людини і природи, взаємозв'язок природних і соціальних чинників; формувати високу культуру екологічного мислення та поведінки особистості; правильно розуміти динаміку народонаселення; давати знання принципів, засобів та форм сучасного світового економічного порядку й стратегії розвитку виробництва та господарювання, дбайливого ставлення до природних та соціальних ресурсів.

Обов’язковими в програмі підготовки даного фахівця повинна бути 
закладена психолого-педагогічна система знань про духовне i психічне життя людини і суспільства, розвиток і вдосконалення психологічних якостей людини як суб'єкта соціальної дії за допомогою різних видів психотренінгу, для ефективного застосування їх у процесі практичної життєдіяльності як у різних сферах суспільного, так й індивідуального життя індивіду. Сюди ж можна віднести набуття систему знань та навичок, що забезпечують здоровий спосіб життя й спрямовані на зміцнення здоров'я особистості для пропаганди їх в суспільстві.

Ігнорування ж проблеми самореалізації людини може стати причиною самознищення всього людства, практично мова йде про своєрідний духовний Чорнобиль, який проявляється у вигляді зростання психічних захворювань, злочинності, алкоголізму, наркоманії і загальної деморалізації.

В цьому плані можна сказати, що назріла необхідність переходу вищої школи від екстенсивного шляху формування знань (який, в основному, полягає в їх засвоєнні на логічному рівні) до інтенсивного, який полягає в застосуванні передових технологій розвитку здібностей самої людини, щоб бути успішними i конкурентоздатними не тільки в межах Україні, але й будь-якій країні світу.

Ймовірно, що для цього необхідно вводити спецкурси, а в ідеалі - й повноцінні курси на рівні 3 філософією, де б студенти опановували не тільки теорію, але й практичні рекомендації по самореалізації особистості, тобто як розвивати свої інтелектуальні здібності, силу волі, інтуїцію, образне мислення, пам’ять (на основі ейдетичного мислення), високу працездатність, лідерські якості тощо.

На даний же час, щоб здобути успішність і розвинути лідерські якості, люди, які вже отримали вищу освіту, потім часто витрачають час і немалі кошти для освоєння різних курсів-психотренінгів, які нерідко проводяться людьми, котрі просто на цьому заробляють гроші, не даючи при цьому грунтовних знань. Тому справжні знання і практичні вміння в напрямі самореалізації особистості повинна давати вища школа, особливо педуніверситети, випускники яких понесуть ці знання школярам, для того щоб зробити їх успішними в житті.

Не секрет також, що в серйозні європейські фірми приймають на роботу штат не стільки за наявності престижного диплому, а за наявності практичних навичок та розвинутих здібностей виконувати дану роботу. Той парадокс, що на чолі фірм в Україні нерідко опиняються колишні «трієчники», а відмінники йдуть найматися до них на роботу означає, що «трієчники» можуть володіти розвинутою силою волі, бути хорошими організаторами, вміти нестандартно мислити, швидко і відповідально приймати рішення тощо.

Нерідко в програмах курсів по розвитку особистості, які читаються в передових європейських вишах, застосовуються елементи йогічної практики. Можна зазначити, що подібне застосування є досить виправданим, оскільки у вік демократії і плюралізму не останнє місце відводиться й позанауковим формам знання, які теж мають право на існування. Порівнюючи, наприклад, науку i систему йоги, то можна вказати на те, що наука орієнтується, в більшій мірі, на 
зовнішній по відношенню до людини світ, намагаючись покращити середовище існування людини. Що стосується системи йоги, то вона має за мету вдосконалення самої людини, беручи за основу розвиток іiі духовного начала. Виходячи 3 цього, доцільно вважати, що обидві ці галузі знань можуть доповнювати одна одну і відігравати свою позитивну роль в розвитку людського суспільства.

Тому одним із способів покращення ситуації з навчанням у вищий школі, на думку автора, являється асиміляція духовних цінностей східної культури, зокрема теорії і практики йоги, яка пропонує цілісну систему вдосконалення людини, своєрідний спосіб життя 3 його орієнтацією на морально-духовні цінності і покращання як здоров'я взагалі, гак й інших функцій організму, в тому числі розумових здібностей, вміння регулювати та програмувати власну поведінку, посилювати власну енергетику та будувати гармонійні відносини 3 самим собою і оточуючими.

До речі, в своїй монографії «Самореалізація особистості: досвід індуїзму та християнства» автор вказував на близькість індуїзму та християнства в його езотеричному аспекті: «Аналізуючи апокрифічну християнську літературу, можна зробити висновок про близькість традицій йогічної практики і методів фізичного вдосконалення в християнстві, оскільки і там, до там було характерним окрім посту, аскетичного способу життя, слідуванню целібату, застосування фізичних вправ, системи дихання, очищувальних процедур, прийняття повітряних, водних, сонячних та грязьових ванн тощо» [8 ].

Як вказував автор статті в інших публікаціях [9], християнство, яке було введене на території нашої країни тисячу років тому, в основному апелювало до емоцій, не переводячи їх в переконання. Це, на думку автора, власне, й породило міф про загадковість слов'янської душі, коли людина, яка не вміє керувати собою, демонструвала здатність до несподіваних і навіть непередбачуваних вчинків, а потім дивувалася їх наслідкам.

Людина ж, яка не володіє мистецтвом психотренінгу, нерідко намагається в буденному житті ввійти в стан зміненої свідомості за допомогою алкоголю чи наркотиків, але, зазвичай, це веде не до духовного зростання, а в кінцевому результаті, до деградації особистості.

Тому автор пропонує для подолання цих негативних тенденцій вводити спецкурси по самореалізації особистості, які повинні на його думку перерости на повноцінні курси поряд 3 такими дисциплінами як філософія, педагогіка, психологія та інші. В такому спецкурсі, розробленим автором, під назвою «Лідерство і основи самореалізації особистості» та який пройшов апробацію у магістрів фізико-математичного факультету НПУ імені М.П.Драгоманова і мав у останніх досить великий успіх, висвітлюються не лише теоретичні питання, такі як, проблема самореалізації в релігійних та філософських та психологічних системах, дається визначення, що таке самореалізація особистості; актуальність самореалізації особистості на даному етапі розвитку людства; основні типи i аспекти самореалізації, критерії і показники самореалізації особистості в різних 
сферах людської життєдіяльності, поняття ілюзорної самореалізації. Але й даються суто практичні рекомендації для розвитку індивідуальних якостей. Щоб зміцнити своє здоров'я, студенти освоюють елементарні, але в той же час, ефективні вправи тібетської та китайської гімнастики, гімнастику давньоєгипетських жерців - систему Гермеса, систему дихальних вправ, в першу чергу, систему Стрельнікової, яка до того ж покращує звучання голосу тощо. До речі, оскільки при врахуванні того факту, що в ході спілкування краще сприймаються люди, які мають поставлений голос, то на семінарських заняттях освоюються ефективні способи його постановки, в тому числі і 3 італійської школи оперного співу.

В свій час Конфуцій сказав: «Які труднощі може зустріти людина в керуванні державою, якщо вона вміє керувати собою?». Без сумніву, є й зворотний зв'язок - людям, в яких втрачена культура володіння собою, важко створити власну державу. Тому в даному спецкурсі відводиться чільне місце освоєнню психотренінгу для розвитку сили волі, інших позитивних моральних якостей, в першу чергу, лідерських, а також пам'яті, інтелекту, свого творчого потенціалу тощо. Цьому ж сприяє заняття по розвитку так званого ейдетичного мислення, яке є вельми ефективним при обробці та запам'ятовуванні великого обсягу інформації, вивченню іноземних мов тощо. Для витримування фізичних і психологічних навантажень, що стрімко зростають, вельми корисною $є$ освоєння теорії і практики так званого керованого сну. Оскільки людина проводить увісні майже третину свого життя, то від якості нашого сну залежить якість нашого денного буття. Студенти тут освоюють, свого роду, культуру входження і виходу зі сну, знайомляться 3 теорією і практикою поліфазного сну, основними прийомами ефективного відпочинку в екстремальних ситуаціях за п'ять хвилин, якими володів ще Олександр Македонський, а також навчаються розвивати творчі здібності і ефективно обробляти інформацію, що надійшла вдень, за принципом «Ранок за вечір є мудрішим».

В руслі цього спецкурсу також освоюються ефективні методи спілкування, де етика розглядається не як набір моральних заповідей чи правил (бажаних, але малоефективних в реальному житті), а як мистецтво побудови відносин між собою та оточуючим світом, що буде сприяти можливості зайняти чільне місце в будь-якій соціальній групі, що дозволяє реалізувати себе як особистість. Студенти утверджуються в думці, що лише високодуховна людина здатна досягти справжнього успіху в житті за будь-яких негативних умов.

Таким чином, цей спецкурс $\epsilon$ ще одним кроком в бік того, щоб вища школа була цікавою і корисною для студентів. Тому покладає надії на його застосуванні в Інституті людини Київського університету імені Бориса Грінченка.

\section{Висновки:}

-Розвиток суспільства та особистісний розвиток людини відносяться один до одного як загальне до конкретного і взаємообумовлюють, взаємовизначають та взаємодоповнюють один одного. Тому проблема самореалізації особистості $\epsilon$ однією з кардинальних проблем сучасності. 
-Процеси демократизації в нашій країні, що почалися чверть століття тому, дозволили по новому поглянути на роль релігії та Церкви. Зараз стає зрозумілим, що релігія як форма суспільної свідомості далеко ще не вичерпала своїх можливостей на даному етапі розвитку людства. В першу чергу, це стосується проблем виховання та розвитку людини. Виникнувши на зорі людства, релігія була покликана, насамперед, виконувати суто практичні функції, першими з яких $\epsilon$ виховання визначеного, найбільш доцільного за певних умов життя, типу особистості та гармонізація відносин «людина - світ» у максимально широкому плані, а також пропонувалася сукупність настанов, правил, способів і прийомів для його досягнення. Інакше кажучи, йдеться про те, що саме релігія, або точніше, релігії різних народів, на наш погляд, пропонували перші концепції самореалізації особистості.

•Формальне слідування Болонській системі веде до серйозних втрат в освітньому процесі.

- $Є$ нагальна потреба у введенні в навчальні плани дисциплін, які давали б змогу репрезентувати людську особистість в аспекті ії самореалізації та надавали б конкретні рекомендації до застосування теорії на практиці.

-Назріла нагальна потреба переходу вищої школи від екстенсивного шляху формування знань (який, в основному, полягає в їх засвоєнні на логічному рівні) до інтенсивного, який полягає в застосуванні передових технологій розвитку здібностей самої людини.

-Одним із способів покращення ситуації з навчанням у вищий школі, на думку автора, являється асиміляція духовних цінностей східної культури, зокрема філософії і практики йоги та християнства в його глибинних езотеричних основах.

\section{Jimepamypa:}

1.Матвеев В.А Самореализация личности / В.А. Матвеев, Н.В. Хамитов // Философская антропология: словарь / под ред. доктора философских наук, профессора Н.Хамитова. - К.: KHT, 2011. - C.319-320.

2.DW: Станислав Петров: человек, который не нажал на "красную кнопку". [Елекронний pecypc]. Режим доступу: https://focus.ua/ukraine/261345

3.Сергій Бабак. Україна технологічно не готова до повноцінного запровадження дистанційного навчання. [Елекронний ресурс].Режим доступу: https://pedpresa.com.ua/202644ukrayina-tehnologichno-ne-gotova-do-povnotsinnogo-zaprovadzhennya-dystantsijnogo-navchannyasergij-babak.html

4.Блатные псы [Елекронний ресурс]. Режим доступу: ://kinoseven.ru/moschnyiy-film-pro90-e-blatnyie-psyi-russk_d539d1a79.html.

5.Концепція нової української школи. [Елекронний ресурс]. Режим оступу: https://mon.gov.ua/ua/tag/nova-ukrainska-shkola

6.Матвєєв В.О. Актуальність і можливі шляхи інтенсифікації навчального процесу у вищій школі / Матвєєв В. О // Гілея. Філософія. Політологія. Історія : наук. вісник : зб. наук. пр./ НПУ ім. М. П. Драгоманова, Українська АН ; голов. ред. В. М. Вашкевич. - К., 2013. Вип. 73 (№6) - С. 284- 296

7.Арцішевський Р.А. Світ і людина: пробний підруч. для 8 кл. / Р.А. Арцішевський. - К.: Освіта, 1992. - 208 с. 
8.Матвєєв В.О. Самореалізація особистості: досвід індуїзму та християнства / В.О. Матвєєв. -Н: „Аспект-Поліграф” 2010. - 339 с.

9.Матвєєв В.О. Езотеричний потенціал християнства в контексті самореалізації особистості / Матвєєв В.О. // Практична філософія. - 2001. - №1.- С.226-232

\section{References}

1.Matveev, V.A., Khamitov, N.V. (2011). Samorealizatsiya lichnosti [Personality Selfrealization]. N. Khamitov (Eds.). Filosofskaya antropologiya - Philosophical Anthropology. (pp. 319320). Kyiv: KNT [in Russian].

2. DW: chelovek, kotoryy ne nazhal na "krasnuyu knopku" [DW: the person who did not press the "red button"]. focus.ua. Retrieved from https://focus.ua/ukraine/261345 [in Russian].

3. Babak, S. (2020). Ukraina tekhnolohichno ne hotova do povnotsinnoho zaprovadzhennia dystantsiinoho navchannia [Ukraine is not technologically ready for the full introduction of distance learning]. pedpresa.com.ua. Retrieved from https://pedpresa.com.ua/202644-ukrayina-tehnologichnone-gotova-do-povnotsinnogo-zaprovadzhennya-dystantsijnogo-navchannya-sergij-babak.html [in Ukrainian].

4. Blatnye psy [Thug dogs]. kinoseven.ru. Retrieved from http://kinoseven.ru/moschnyiy-filmpro-90-e-blatnyie-psyi-russk_d539d1a79.html [in Russian].

5. Kontseptsiia novoi ukrainskoi shkoly [The concept of a new Ukrainian school]. mon.gov.ua. Retrieved from https://mon.gov.ua/ua/tag/nova-ukrainska-shkola [in Ukrainian].

6. Matvieiev, V.O. (2013). Aktualnist i mozhlyvi shliakhy intensyfikatsii navchalnoho protsesu $\mathrm{u}$ vyshchii shkoli [Relevance and possible ways to intensify the educational process in higher education]. Hileia. Filosofiia. Politolohiia. Istoriia - Gileya. Philosophy. Politology. History, 73(6), 284-296 [in Ukrainian].

7. Artsishevskyi, R.A. (1992). Svit i liudyna [The world and a man]. Kyiv: Osvita [in Ukrainian].

8. Matvieiev, V.O. (2010). Samorealizatsiia osobystosti: dosvid induizmu ta khrystyianstva [Self-realization of personality: experience of Hinduism and Christianity]. Nizhyn: „Aspekt-Polihraf” [in Ukrainian].

9. Matvieiev, V.O. (2001). Ezoterychnyi potentsial khrystyianstva v konteksti samorealizatsii osobystosti [Esoteric potential of Christianity in the context of self-realization of personality]. Praktychna filosofiia - Practical philosophy, 1, 226-232 [in Ukrainian]. 